\title{
Sistem Pakar Mendiagnosa Penyakit Ayam Kampung Dengan Menggunakan Metode Certainty Factor Berbasis Web
}

\author{
Ida Royani Simanungkalit ${ }^{*}$, Bosker Sinaga ${ }^{2}$ \\ ${ }^{1,2}$ STMIK Pelita Nusantara \\ Jl. Iskandar Muda No. 1 Medan 20154 Indonesia \\ Corresponding author‘s e-mail: idhar6215@gmail.com
}

\begin{abstract}
Abstrak - Budidaya ternak unggas di Indonesia masih belum berhasil dalam memenuhi sebagian dari kebutuhan dalam negeri, termasuk rentan terhadap serangan penyakit hewan berbahaya. Masyarakat juga resah karena penyakit berbahaya dari ayam yang bisa saja menular ke manusia akibat mengkonsumsi daging ayam yang sudah terjangkit penyakit. Studi kasus dalam melakukan penelitian untuk mendiagnosa penyakit ayam kampung ini dilakukan pada Peternakan Ayam Kampung Bang Ari di Jalan Jamin Ginting Komplek Pamen No.14 Padang Bulan Kecamatan Medan Baru Kota Medan. Data kriteria yang dibutuhkan merupakan jenis penyakit dan gejala gejala penyakit yang menyerang ayam kampung serta tindakan pengobatan yang akan dilakukan terhadap ayam kampung yang terjangkit penyakit sesuai penyakit yang dialami. Penelitian ini bertujuan membangun sistem pakar berbasis web dalam mendiagnosa penyakit ayam kampung menggunakan metode certainty factor. Dari contoh kasus, hasil perhitungan certainty factor pada gejala ayam kampung, maka penyakit yang memiliki nilai persentase terbesar adalah P 7 yaitu Penyakit Batuk Manahun sebesar $97.50 \%$. Sistem untuk mendiagnosa penyakit ayam kampung dibangun dengan menggunakan bahasa pemrograman berbasis web dan database MySQL.
\end{abstract}

Kata kunci: Penyakit Ayam Kampung, Diagnosa, Sistem Pakar, Certainty Factor

Abstract - Poultry farming in Indonesia is still not successful in meeting some of the domestic needs, including being vulnerable to attacks by dangerous animal diseases. People are also restless because of dangerous diseases from chickens that can be transmitted to humans due to consuming chicken meat that has been infected with the disease. The case study in conducting research to diagnose free-range chicken disease was carried out at the Bang Ari Chicken Farm on Jalan Jamin Ginting Pamen Complex No.14 Padang Bulan, Medan Baru District, Medan City. The required criteria data is the type of disease and symptoms of the disease that attacks native chickens as well as the treatment actions that will be taken against the diseased chickens according to the disease experienced. This study aims to build a web-based expert system in diagnosing freerange chicken diseases using the certainty factor method. From the case example, the results of the calculation of certainty factor on the symptoms of free-range chickens, the disease that has the largest percentage value is P 7, namely Chronic Cough Disease of $97.50 \%$. The system for diagnosing free-range chicken disease was built using a web-based programming language and MySQL database.

Keywords: Chicken Disease, Diagnosis, Expert System, Certainty Factor

\section{Pendahuluan}

Masyarakat pada umumnya minim pengetahuan tentang diagnosa penyakit ayam kampung sehingga untuk melakukan pengobatan penyakit tersebut secara detail yang dialami oleh penderita diperlukan bantuan seorang pakar agar memperoleh hasil diagnosa yang akurat dan terpercaya terhadap penyakit ayam kampung yang dialami, apalagi masyarakat yang berasal dari pedesaaan yang minim pengetahuan tentang apa yang dimaksud dengan penyakit ayam kampung. Adapun masalah yang sering terjadi dalam situasi melaksanakan pelayanan pakar terhadap pasien untuk melakukan diagnosa ayam kampung adalah kurang efektifnya pemanfaatan waktu dalam proses membuat keputusan hasil diagnosa dikarenakan banyak pasien yang harus dilayani dalam berkonsultasi, sehingga aktivitas yang dilaksanakan tidak efektif untuk melayani banyak pasien serta waktu yang tidak mencukupi bagi pasien untuk berkonsultasi sama dokter karena kesibukan dengan aktivitas pekerjaan dan lebih parahnya lagi bahwa dikalangan masyarakat pedesaaan tidak tersedianya seorang pakar yang menangani atau yang ahli dalam mendiagnosa penyakit ayam kampung.

Mengatasi permasalahan yang dijelaskan di atas secara efektif pada proses melakukan diagnosa penyakit ayam kampung diperlukan adanya suatu pengembangan sistem berbasis komputer berupa aplikasi yaitu sistem pakar (expert system). Oleh sebab itu pada penelitian ini merancang aplikasi sistem pakar (expert system) menggunakan bahasa pemrograman yang berbasis web [1]. Pada sistem pakar diagnosa penyakit ayam kampung ini akan diterapkan metode certainty factor guna menghasilkan keputusan diagnosa yang cepat dan tepat terkait dengan diagnosa penyakit ayam kampung. Teori metode certainty factor ini diharapkan dapat mengurangi ketidakpastian sehingga dapat menghasilkan diagnosis yang valid.

Sistem pakar adalah suatu sistem yang dirancang untuk dapat menirukan keahlian seorang pakar dalam 
menjawab pertanyaan dan memecahkan suatu masalah. Sistem pakar akan memberikan pemecahan suatu masalah yang didapat dari dialog dengan pengguna. Sistem pakar adalah sebuah sistem yang kinerjanya mengadopsi keahlian yang dimiliki seorang pakar dalam bidang tertentu ke dalam sistem atau program komputer yang disajikan dengan tampilan yang dapat digunakan oleh pengguna yang bukan seorang pakar sehingga dengan sistem tersebut pengguna dapat membuat sebuah keputusan atau menentukan kebijakan layaknya seorang pakar [2]. Sistem pakar (expert system) merupakan sistem yang berusaha untuk mengadopsi kemampuan atau pengetahuan manusia ke dalam komputer, agar komputer dapat bekerja dalam menyelesaikan suatu masalah seperti layaknya seorang pakar atau sesorang yang mempunyai keahlian dalam bidang tertentu, yaitu pakar yang mempunyai knowledge atau kemampuan khusus yang tidak diketahui dan dimiliki oleh orang lain. Sistem pakar merupakan cabang dari Artificial Intelligence (AI) [3]. Salah satu metode sistem pakar yang dapat menghitung ketidakpastian dalam sebuah topik permasalahan dapat dilakukan dengan menggunakan metode certainty factor[4]. Certainty factor adalah suatu metode untuk membuktikan apakah suatu fakta itu pasti ataukah tidak pasti yang berbentuk metric yang biasanya digunakan dalam sistem pakar. Metode ini sangat cocok untuk sistem pakar yang mendiagnosis sesuatu yang belum pasti [5]. Metode ini merupakan perhitungan tingkat kepastian terhadap kesimpulan yang diperoleh dan dihitung berdasarkan nilai probabilitas penyakit karena ayam adanya evident gejala. Diharapkan dengan penggunaan metode certainty factordapat mengurangi ketidakpastian sehingga dapat menghasilkan diagnosis yang valid [6].

Penelitian Implementasi Metode Certainty Factor Dalam Sistem Pakar menjelaskan Sistem pakar dapat melakukan penelusuran rule, menerapkan model probabilistik tingkat ukuran ketidakpastian untuk evaluasi nilai preferensi pengetahuan pakar [7]. Penelitian Implementasi Metode Certainty Factor pada Sistem Pakar Diagnosa Penyakit Ayam Berbasis Android menjelaskan Certainty Factor merupakan sebuah metode untuk mengakomodasi ketidakpastian pemikiran (inexact reasoning) seorang pakar. Seorang pakar (contoh: dokter) sering menganalisi informasi dengan ungkapan "mungkin ", "kemungkinan besar", "hampir pasti" [8]. Penelitian Sistem Pakar untuk Diagnosa Penyakit Ayam Pedaging menjelaskan Metode yang digunakan untuk membangun sistem ini adalah waterfall dengan teknik forward chaining sebagai solusi runut maju artinya inferensi dilakukan dengan mencari data masukan berupa data gejala berupa penyakit ayam. Sistem [9].

\section{Tinjauan Pustaka}

\subsection{Kecerdasan Buatan}

Artificial intellegence atau kecerdasan buatan adalah kecerdasan yang merujuk pada mesin yang mampu berpikir, menimbang tindakan yang akan diambil dan mampu mengambil keputusan seperti yang dilakukan manusia [10]. Kecerdasan buatan adalah salah satu bidang ilmu komputer yang mendayagunakan komputer sehingga dapat berperilaku cerdas seperti manusia. Teknologi kecerdasan buatan dipelajari dalam berbagai bidang, seperti Robotika (Robotics), Penglihatan Komputer (Computer Vision), Pengolahan Bahasa Alami (Natural Language Processing), Pengenalan Pola (Pattern Recognition), Sistem Syaraf Buatan (Artificial Neural System), Pengenalan Suara (Speech Recognition), dan Sistem Pakar (Expert System). Dua bagian utama dibutuhkan untuk aplikasi kecerdasan buatan [11]:

1. Basis pengetahuan (knowledge base): berisi fakta-fakta, teori, pemikiran dan hubungan antara satu dengan lainnya.

2. Motor Inferensi (inference engine): kemampuan menarik kesimpulan berdasarkan pengalaman.

\subsection{Dasar Teori}

Sistem adalah suatu jaringa kerja dari prosedur-prosedur yang saling berhubungan, berkumpul bersama-sama untuk melakukan suatu kegiatan tertentu untuk mencapai tujuan tertentu. Pakar adalah seseorang individu yang memiliki pengetahuan khusus, pemahaman, pengalaman, dan metode-metode yang digunakan untuk memecahkan persoalan dalam bidang tertentu [12]. Sistem pakar adalah suatu sistem yang dirancang untuk dapat menirukan keahlian seorang pakar dalam menjawab pertanyaan dan memecahkan suatu masalah. Sitem pakar akan memberikan pemecahan suatu masalah yang didapat dari dialog dengan pengguna. Ada 2 cara dalam melakukan inferensi:

1. Forward Chaining

Pencocokan fakta atau pernyataan dimulai dari fakta terlebih dahulu, untuk menguji kebenaran hipotesis.

2. Backward Chaining

Pencocokan fakta atau pernyataan dimulai dari hipotesis terlebih dahulu, dan untuk menguji kebenaran hipotesis tersebut harus dicari fakta-fakta yang ada dalam basis pengetahuan).

Certainty Factor adalah suatu metode untuk membuktikan apakah suatu fakta itu pasti ataukah tidak pasti yang berbentuk metric yang biasanya digunakan dalam sistem pakar [13]. Metode ini sangat cocok untuk sistem pakar yang mendiagnosis sesuatu yang belum pasti. Nilai Certainty Factor ada 2, yaitu [14]:

1. Nilai Certainty Factor kaidah yang nilainya melekat pada suatu kaidah/rule tertentu dan besarnya nilai 
diberikan oleh pakar.

2. Nilai Certainty Factor yang diberikan oleh pengguna untuk mewakili derajat kepastian/keyakinan atas premis (misalnya gejala, kondisi, ciri) yang dialami pengguna.

\section{Metode Penelitian}

Langkah-langkah dari kerangka kerja, yang berguna untu memudahkan dalam melakukan penelitian.

1. Identifikasi dan Rumusan Masalah

Pada kegiatan ini peneliti menjelaskan permasalahan sebagai latar belakang penelitian dan tujuan yang akan dicapai. Permasalahan dalam penelitian ini berasal dari studi literatur yang telah dipelajari oleh peneliti.

2. Pengumpulan Data

Pada tahap ini peneliti memahami melakukan pengumpulan data dengan studi literatur informasi penelitian dari buku maupun jurnal untuk mendukung penulisan yang berkaitan dengan topik yang diangkat dan wawancara.

a) Memahami penyakit-penyakit pada Ayam Kampung. Penyakit- penyakit yang dapat menyerang Ayam Kampung dikumpulkan dan dianalisa gejala-gejala dari masing-masing penyakit tersebut beserta cara penanganan dan penanggulangannya.

b) Memahami konsep sistem pakar. Pemahaman terhadap konsep sistem pakar ini merupakan hal dasar dan sangat berpengaruh dalam melakukan penelitian. Diantaranya konsep dasar sistem pakar, ciri-ciri sistem pakar, kelebihan dan kekurangan sistem pakar, dan komponen sistem pakar. Komponen sistem pakar mencakup User, Interface, basis pengetahuan, akuisisi pengetahuan dan Inference Engine.

c) Memahami metode Certainty Factor. Metode Certainty Factor merupakan cara dari penggabungan kepercayaan (belief) dan ketidapercayaan (unbelief) dalam bilangan yang tunggal. Certainty Factor menunjukkan ukuran.

d) Menentukan tujuan penelitian Penentuan tujuan penelitian berfungsi untuk memperjelas tentang apa saja yang menjadi sasaran dari penelitian ini yaitu merancang aplikasi sistem pakar diagnosa penyakit pada Ayam Kampung dengan metode Certainty Factor berbasis web.

e) Wawancara

Akuisisi Pengetahuan Setelah melakukan studi literatur dari jurnal dan buku serta informasi dari internet yang berhubungan dengan penelitian yang dilakukan, penulis melakukan wawancara dengan pakar dengan memberikan beberapa pertanyaan umum mengenai penyakit pada Ayam Kampung dan daftar penyakit, gejala penyakit yang telah didapat dari jurnal, buku dan sumber lainnya. Setelah itu pakar mengisi nilai keyakinan Certainty Factor dari gejala penyakit tersebut terhadap penyakit pada Ayam Kampung beserta pencegahan dan pengobatannya.

3. Analisa Data

Untuk menganalisa data diperlukan beberapa langkah-langkah kerja sebagai berikut :

a. Menentukan Kebutuhan Data Penentuan data yang dibutuhkan berfungsi untuk memperjelas tentang data yang diperlukan dalam pembangunan sistem pakar ini.

b. Pembentukan Basis Pengetahuan Pada tahap ini setelah dilakukan studi literatur dari jurnal dan buku, dibentuklah basis pengetahuan berupa:

1) Basis pengetahuan penyakit Ayam Kampung Basis pengetahuan ini berisi penyakit-penyakit yang dapat menyerang Ayam Kampung.

2) Basis pengetahuan gejala penyakit Basis pengetahuan ini berisi gejala dari penyakit-penyakit yang dapat menyerang Ayam Kampung.

3) Basis pengetahuan relasi penyakit dan gejala beserta bobot Certainty Factor. Merupakan gabungan dari penyakit dan gejalanya dan bobot nilai keyakinan yang didapat dari pakar.

4) Basis pengetahuan pencegahan dan pengobatan Basis pengetahuan ini berisi solusi berupa pencegahan dan pengobatan dari penyakit- penyakit yang dapat menyerang Ayam Kampung.

5) Inference Engine Pada tahap ini, peneliti melakukan penalaran terhadap penyakit-penyakit tersebut. Dimulai dari IF berupa gejala penyakit Ayam Kampung sehingga memperoleh konklusi THEN berupa penyakit yang menyerang Ayam Kampung.

c. Perbaikan Basis Pengetahuan Berdasarkan langkah sebelumnya, basis pengetahuan diperbaiki sehingga membentuk sebuah basis pengetahuan yang baik dan penalaran yang lebih efektif akan dihasilkan.

4. Perancangan Sistem

Setelah melakukan analisa, tahap selanjutnya adalah perancangan sebuah sistem. Sebagai output dari analisa akan dibuat beberapa diagram untuk memudahkan pembaca dalam mengambil intisari dari analisa.

5. Implementasi Sistem

Pada tahap ini hasil dari analisa dan perancangan akan diimplementasikan melalui proses pengkodingan.

6. Pengujian Sistem. 
Setelah pengkodingan selesai sistem akan diuji untuk memastikan sistem dapat bekerja sesuai dengan tujuan yang diharapkan.

\section{Hasil dan Pembahasan}

Analisa Data Penyakit dan Gejala. Pengetahuan yang diperoleh dari hasil wawancara dan analisa lewat buku dikonversi ke dalam sebuah tabel penyakit dan gejala guna mempermudah proses pencarian solusi. Data jenis penyakit dan gejala ini digunakan sebagai pola pencocokan informasi yang dimasukan oleh pemakai dan basis pengetahuan.

Tabel 1. Data Penyakit Ayam Kampung

\begin{tabular}{|l|l|l|}
\hline Kode Penyakit & \multicolumn{1}{|c|}{ Nama Penyakit } & \multicolumn{1}{|c|}{ Bahasa Latin } \\
\hline P001 & Flu Burung & AvianInfluenza \\
\hline P002 & KoleraAyam & Fowl Cholera \\
\hline P003 & Penyakit Berak Kapur & Pullorum Disease \\
\hline P004 & Tetelo & NewcastleDisease \\
\hline P005 & Berak Darah & Coccidosis \\
\hline P006 & Gumboro & Gumboro Disease \\
\hline P007 & Snot & Coryza \\
\hline P008 & Penyakit Batuk Menahun & Infectious Coryza \\
\hline P009 & Pernapasan Menahun & Chronic Respiratort Disease \\
\hline P010 & Penyakit Berak Kuning & Colibacillosis \\
\hline
\end{tabular}

Pada tabel jenis penyakit dan gejala terdapat dua jenis penyakit yang ditujukan oleh P001, P002, .. P010 dan 37 gejala yang ditunjukkan oleh G001, G002, .., G037. Dari 37 gejala dan 10 jenis penyakit disusun sebuah relasi yang dijadikan sebagai landasan dalam pengambilan kesimpulan. Analisis Sistem yang Dibangun. Sistem yang dibuat oleh penulis dirancang agar dapar digunakan oleh berbagai kalangan. Hal ini dikarenakan pemilik peternakan ayam kampung. Dalam desain sistem yang dibuat oleh penulis, memiliki beberapa kemampuan yaitu .

1. Mampu untuk mendiagnosa penyakit sesuai gejala yang terjadi.

2. Menampilkan informasi penyakit dan cara mengatasinya.

3. Mempunyai fitur khusus (Admin) dalam mengelola data aturan (Rule), data gejala maupun data penyakit.

Analisa Metode Certainty factor. Penerapan metode Certainty factor pada sistem pakar dibutuhkan beberapa kumpulan aturan, masing-masing aturan tersebut memiliki nilai bobot keyakinan yang ditentukan oleh pakar. Pakar memberikan nilai untuk tiap aturan dengan skala nilai aturan berkisar antara 0 hingga 1 . Aturan dibangun berdasarkan klausa IF-THEN. Metode certainty factor memiliki nilai kepastian. Nilai kepastian dari pakar, Tidak Tahu $\mathrm{CF}=0$, Tidak $\mathrm{CF}=0.2$, Sedikit Yakin $\mathrm{CF}=0.4$, Cukup Yakin $\mathrm{CF}=0.6$, Yakin $\mathrm{CF}=0.8$, Sangat Yakin $\mathrm{CF}=1$.

\section{Perhitungan Certainty Factor}

Sebagi contoh, seorang peternak datang konsultasi kepada sistem pakar untuk mengetahui penyakit ayam kampung berdasarkan gejala yang dialami sebagai berikut:

Tabel 2. Gejala yang dipilih

\begin{tabular}{|l|c|c|}
\hline \multicolumn{1}{|c|}{ Gejala Terpilih } & CF Pakar & CF User \\
\hline G1 : Nafsu makan berkurang & 0.4 & 0.8 \\
\hline G2 : Nafas sesak/ megap-megap & 0.6 & 0.2 \\
\hline G3 : Nafas ngorok & 0.6 & 0.8 \\
\hline G6 : Diare & 0.2 & 0.2 \\
\hline G7 : Produksi TelurMenurun & 0.2 & 0.4 \\
\hline
\end{tabular}

Perhitungan Nilai CF pada Penyakit P1 (Flu Burung)

CF1 $=$ CFpakar $*$ CFuser $=0.32$

$\mathrm{CF} 2=\mathrm{CFpakar} * \mathrm{CFuser}=0.12$

CF3 $=$ CFpakar $*$ CFuser $=0.48$

$\mathrm{CF} 4=$ CFpakar $*$ CFuser $=0.4$

$\mathrm{CF} 3=$ CFpakar $*$ CFuser $=0.8$

Mengkombinasikan nilai CF pada $\mathrm{P} 1$

CFcombine CF[h,e]1,2 =CF[h,e]1 + CF[h,e $2 *(1-\mathrm{CF}[\mathrm{h}, \mathrm{e}] 1)=0.4016$

CFcom CF[h,e]1,3 =CF[h,e]1 + CF[h,e] $3 *(1-\mathrm{CF}[\mathrm{h}, \mathrm{e}] 1)=0.6888$ 
CFcom CF[h,e] $2,4=\mathrm{CF}[\mathrm{h}, \mathrm{e}] 2+\mathrm{CF}[\mathrm{h}, \mathrm{e}] 4 *(1-\mathrm{CF}[\mathrm{h}, \mathrm{e}] 2)=0.81328$

CFcom CF[h,e] $3,5=\mathrm{CF}[\mathrm{h}, \mathrm{e}] 3+\mathrm{CF}[\mathrm{h}, \mathrm{e}] 5 *(1-\mathrm{CF}[\mathrm{h}, \mathrm{e}] 3)=0.9626$

Maka nilai CF maka P1 adalah CFpersentase $=C F$ com $* 100 \%=96.26 \%$

Perhitungan Nilai CF pada Penyakit P2 (Kolera Ayam)

$\mathrm{CF} 1=$ CFpakar $*$ CFuser $=0.32$

$\mathrm{CF} 2=\mathrm{CFpakar} * \mathrm{CFuser}=0.12$

$\mathrm{CF} 3=\mathrm{CFpakar} * \mathrm{CFuser}=0.16$

$\mathrm{CF} 4=\mathrm{CFpakar} * \mathrm{CFuser}=0.12$

$\mathrm{CF} 3=$ CFpakar $*$ CFuser $=0.12$

Mengkombinasikan nilai CF pada $\mathrm{P} 2$.

CFcombine CF[h,e]1,2 =CF[h,e]1 $+\mathrm{CF}[\mathrm{h}, \mathrm{e}] 2 *(1-\mathrm{CF}[\mathrm{h}, \mathrm{e}] 1)=0.4016$

CFcom CF[h,e]1,3=CF[h,e] $1+\mathrm{CF}[\mathrm{h}, \mathrm{e}] 3 *(1-\mathrm{CF}[\mathrm{h}, \mathrm{e}] 1)=0.4873$

CFcom CF[h,e]2,4=CF[h,e] $2+\mathrm{CF}[\mathrm{h}, \mathrm{e}] 4 *(1-\mathrm{CF}[\mathrm{h}, \mathrm{e}] 2)=0.5576$

$\mathrm{CF}$ com CF[h,e] $3,5=\mathrm{CF}[\mathrm{h}, \mathrm{e}] 3+\mathrm{CF}[\mathrm{h}, \mathrm{e}] 5 *(1-\mathrm{CF}[\mathrm{h}, \mathrm{e}] 3)=0.6106$

Maka nilai CF maka P2 adalah CFpersentase $=C F$ com $* 100 \%=61.06 \%$

Untuk perhitungan nilai CF pada tiap penyakit sebagai berikut :P3 (Penyakit Berak Kapur)

CFpersentase $=$ CF com $* 100 \%=90.72 \%$

$\mathrm{P} 4$ (Tetelo). CFpersentase $=C F$ com $* 100 \%=86,75 \%$

P5 (Berak Darah). CFpersentase $=C F$ com $* 100 \%=66,4 \%$

P6 (Gumboro). $\mathrm{mCFpersentase}=C F$ com $* 100 \%=92.8 \%$

P7 (Snot). CFpersentase $=$ CF com $* 100 \%=85.6 \%$

P8 (Penyakit Batuk Manahun). CFpersentase $=$ CF com $* 100 \%=97,50 \%$

P9 (Pernapasan Manahun). CFpersentase $=C F$ com $* 100 \%=84.27 \%$

P10 (Penyakit Berak Kuning). CFpersentase $=$ CF com $* 100 \%=84.2 \%$

Berdasarkan dari hasil perhitungan certainty factor pada gejala ayam kampung, maka penyakit yang memiliki nilai persentase terbesar adalahP7 yaitu Penyakit Batuk Manahun sebesar 97.50\%.

Use Case Diagram, menggamarkan user sebagai aktor dalam menjalankan sistem ini. user dapat mendiagnosa penyakit ayam kampung sesuai dengan kondisi ayam kampung serta melihat informasi penyakit dan cara penanganannya.

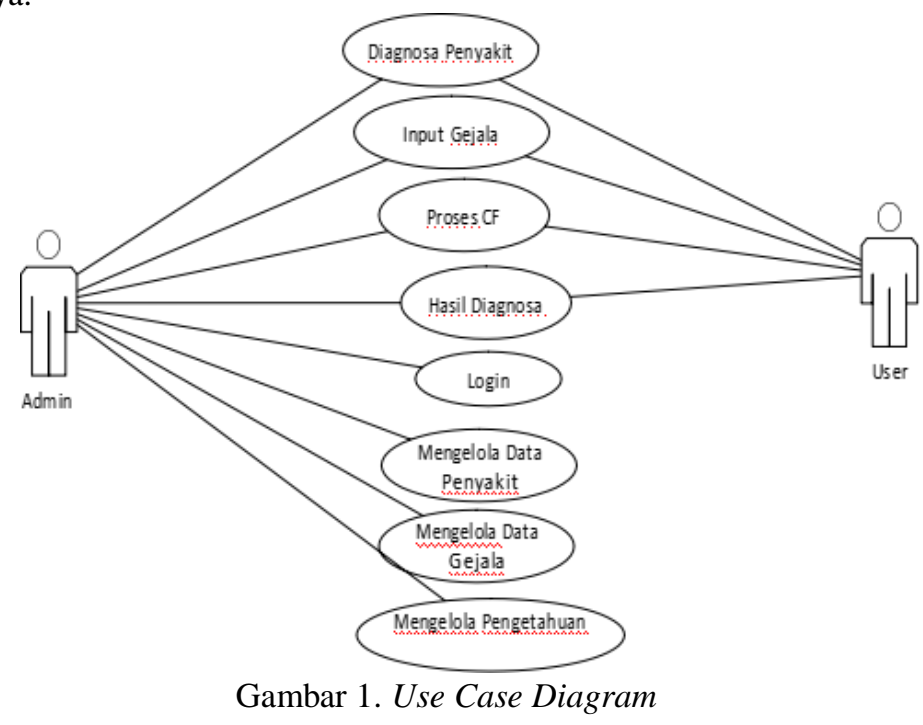

Implementasi sistem adalah tahapan dimana sistem atau aplikasi siap untuk dioperasikan pada keadaan yang sebenarnya sesuai dari hasil analisis dan rancangan form.

1. Halaman Beranda User

Untuk melihat halaman beranda user tidak diharuskan login terlebih dahulu, user bisa melakukan diagnosa langsung pada halaman tersebut, menu yang terdapat yaitu diagnosa, riwayat, keterangan, info harga. 


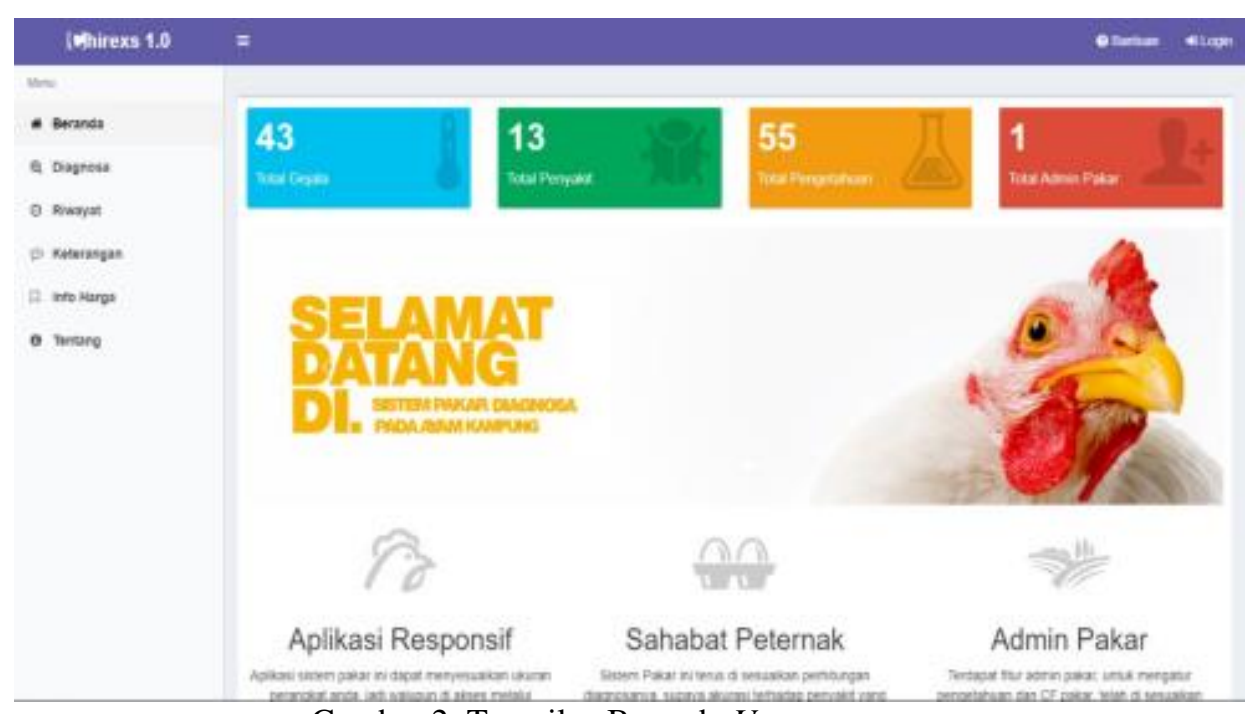

Gambar 2. Tampilan Beranda User

2. Tampilan Halaman Penyakit - Halaman Gejala

Tampilan Halaman Penyakit. pada halaman penyakit admin dapat menambah data penyakit, mengedit data penyakit dan menghapus data penyakit, Untuk menambahkan penyakit, admin dapat menekan tombol tambah data. Tampilan Halaman Gejala, pada halaman gejala admin dapat menambah data gejala, mengedit data penyakit dan menghapus data gejala, tombol tambah data.

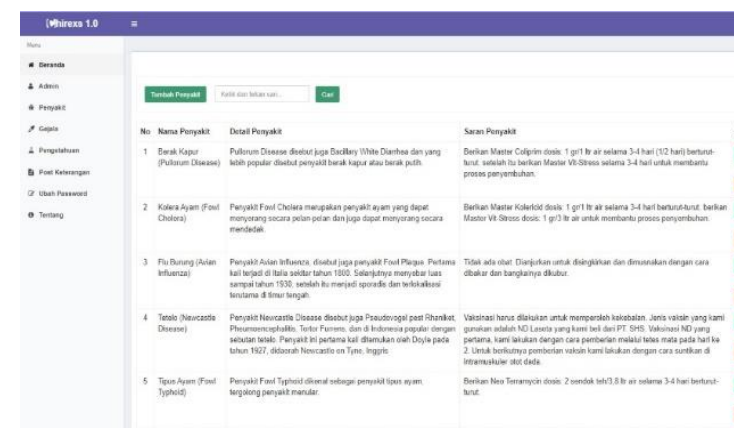

Gambar 3. Halaman Penyakit Ayam Kampung

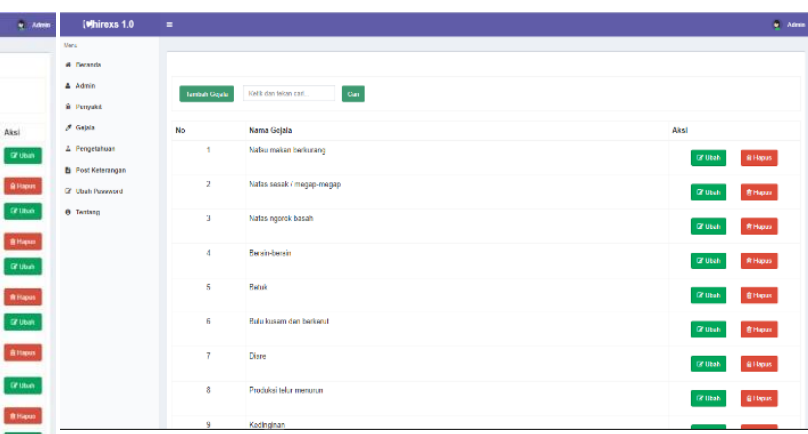

Gambar 4. Halaman Gejala

\section{Tampilan Halaman Diagnosa}

Pada halaman diagnosa user bisa memilih gejala yang terjadi pada ayam dengan memilih kondisi yang telah pada tiap gejala, setelah user memilih gejala selanjutnya menekan tombol diagnosa yang berada pada sudut kiri bawah, maka hasil diagnosa ayam akan muncul berdasarkan gejala yang dipilih dan menampilkan penyakit yang diderita beserta detail dan solusi.

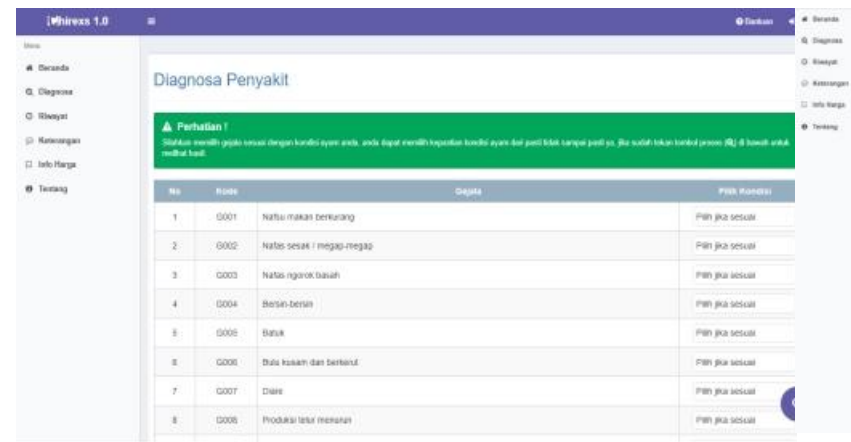

Gambar 5. Halaman Diagnosa

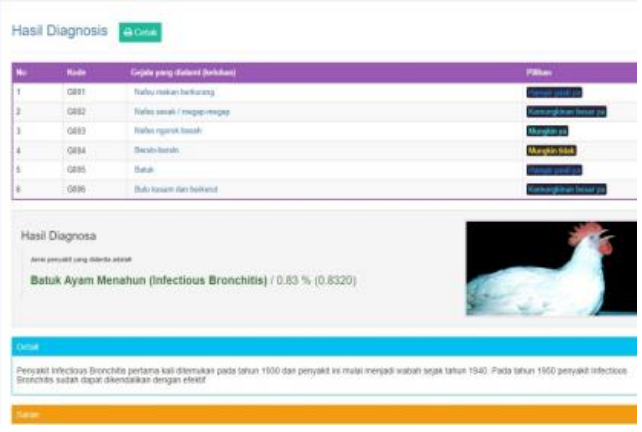

Gambar 6. Hasil Diagnosa 


\section{Kesimpulan}

Adapun kesimpulan penelitian sebagai berikut:

1. Dengan menerapkan certainty factor dalam mendiagnosa penyakit ayam kampung dapat menghasilkan perhitungan valid sehingga proses konsultasi dapat dilakukan dengan cepat dan akurat.dilanjutkan.

2. Untuk menjaga dan memelihara keakuratan data maka perlu dilakukan proses update basis pengetahuan secara berkala.

3. Penambahan metode dan penyempurnaan terhadap aturan-aturan yang digunakan dalam penarikan kesimpulan.

4. Penambahan fitur-fitur tambahan agar aplikasi yang dibuat lebih menarik.

\section{Daftar Pustaka}

[1] N. Yousif et al., "SISTEM PAKAR UNTUK MENGIDENTIFIKASI KEPRIBADIAN SISWA MENGGUNAKAN METODE CERTAINTY FACTOR DALAM MENDUKUNG PENDEKATAN GURU," J. Phys. Ther. Sci., vol. 9, no. 1, pp. 1-11, 2018.

[2] J. Jtik, J. Teknologi, R. Al, D. Yunas, A. Triayudi, and I. D. Sholihati, "Implementasi Sistem Pakar untuk Mendeteksi Virus Covid-19 dengan Perbandingan Metode Naïve Bayes dan Certainty Factor,” vol. 5, no. 3, 2021.

[3] N. Sri and A. Sindar, "Kedelai Menggunakan Metode Certainty Factor," vol. 5, no. 1, pp. 36-41, 2018.

[4] C. S. A. Harahap and B. Sinaga, "Implementasi Metode Certainty Factor Untuk Mendiagnosa Kondisi Psikis Siswa-Siswi SMA Dalam Menghadapi Ujian Nasional Berbasis Komputer (UNBK)," J. Nas. Komputasi dan Teknol. Inf., vol. 3, no. 2, pp. 97-102, 2020.

[5] A. Anggrawan, S. Satuang, and M. N. Abdillah, "Sistem Pakar Diagnosis Penyakit Ayam Broiler Menggunakan Forward Chaining dan Certainty Factor," MATRIK J. Manajemen, Tek. Inform. dan Rekayasa Komput., vol. 20, no. 1, pp. 97-108, 2020.

[6] S. Rahayu and A. S. R. Sinaga, "Penerapan Metode Naive Bayes Dalam Pemilihan Kualitas Jenis Rumput Taman CV. Rumput Kita Landscape,” Digit. Zo. J. Teknol. Inf. dan Komun., vol. 9, no. 2, pp. 162-171, 2018.

[7] P. Sugiartawan, P. Teknologi, R. Perangkat, P. Pertanian, N. Samarinda, and P. T. Informatika, "IMPLEMENTASI METODE CERTAINTY FACTOR DALAM SISTEM PAKAR," vol. 4, no. 2, pp. 195-201, 2021.

[8] M. Muqorobin, P. B. Utomo, M. Nafi'Uddin, and K. Kusrini, "Implementasi Metode Certainty Factor pada Sistem Pakar Diagnosa Penyakit Ayam Berbasis Android," Creat. Inf. Technol. J., vol. 5, no. 3, p. $185,2019$.

[9] W. Kusrini, F. Fathurrahmani, and R. Sayyidati, "Sistem Pakar untuk Diagnosa Penyakit Ayam Pedaging," Edumatic J. Pendidik. Inform., vol. 4, no. 2, pp. 75-84, 2020.

[10] A. Agusta, F. Y. Arini, and R. Arifudin, "Implementation of Fuzzy Logic Method and Certainty Factor for Diagnosis Expert System of Chronic Kidney Disease," J. Adv. Inf. Syst. Technol., vol. 2, no. April, pp. 61-68, 2020.

[11] E. I. Anna and M. B. Hartanto, "Sistem Pakar Untuk Diagnosis Penyakit Ayam Dengan Menggunakan Metode Certainty Factor ( CF ) Berbasis Web," vol. 2, no. 1, pp. 1-13, 2021.

[12] S. Informasi, "Ayam Berbasis Website Menggunakan Metode Certainty Factor Expert System Application for Diagnose the Chicken Disease Based on Website Using Certainty Factor," J. Elektro Luceat, vol. 7, no. 1, $1 \mathrm{AD}$.

[13] M. Arifin, S. Slamin, and W. E. Y. Retnani, "Penerapan Metode Certainty Factor Untuk Sistem Pakar Diagnosis Hama Dan Penyakit Pada Tanaman Tembakau," Berk. Sainstek, vol. 5, no. 1, p. 21, 2017.

[14] C. L. Andesti, S. Sumijan, and G. W. Nurcahyo, "Expert System in Accuracy to Identify Gingivitis in Humans Using the Certainty Factor Method,” J. Inf. dan Teknol., vol. 2, pp. 97-103, 2020. 